\title{
Ósæðarlokuskipti - á leið inn í nýja tíma?
}

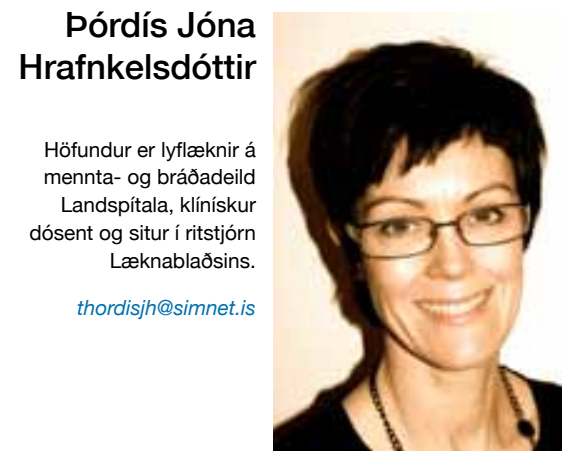

Í pessu tölublaði Læknablaðsins birtist tímabær samantekt á ósæðarlokuskiptum vegna ósæðarlokuprengsla á Landspítala á árunum 2002-2006. Par er fjallað um snemmkomna fylgikvilla og skurðdauða og tekin saman pau einkenni sjúklinga sem leiddu til aðgerðar. Sjúklingahópurinn er nokkuð aldraður, meðalaldur nær 72 árum, ${ }^{1}$ enda er algengasta ástæða ósæðarlokuprengsla kölkun í blöðkunni sem er afleiðing bólgu- og hrörnunarferils sem minnir um margt á æðakölkun, og eru áhættupættir flestir hinir sömu. Niðurstöður rannsóknarinnar benda til pess að skurðdauði sé sambærilegur hér á landi og erlendis og eru pað̀ mikilvægar upplýsingar. Pegar rýnt er í samsetningu hópsins sem lést í tengslum við aðgerðina pá voru pað sjúklingar með mjög mikil einkenni og afar svæsin ósæðarlokuprengsli, auk annarra ípyngjandi sjúkdóma.

Erlendar rannsóknir benda til pess að milli 2,8-4,6\% einstaklinga eldri en 75 ára séu með meðalmikil til svæsin ósæðarlokuprengsli. ${ }^{2}$ Einu upplýsingarnar um algengi ósæðalokuprengsla hér á landi eru úr krufningum frá áttunda áratugnum og var pað áætlað um 3,2\% hjá körlum og $4,5 \%$ meðal kvenna. ${ }^{3}$

Ósæðarlokuprengsli eru pví nokkuð algeng, en eina leiðin til að greina einkennalausa einstaklinga er með hjartahlustun og hjartaómskoðun í framhaldi af pví. Er pví ástæða til að hvetja alla lækna til að hlusta hjörtu eldri skjólstæðinga sinna og gera viðeigandi ráđstafanir, jafnvel pótt um aldraða einstaklinga sé að ræða, nema að ljóst sé að lífslíkur peirra takmarkist af öðrum páttum.

Enda pótt slá megi tímabundið á einkenni og áhættupætti ósæðarlokuprengsla með lyfjameðferð, hefur slík meðferð ekki reynst hafa áhrif á sjúkdómsganginn. Eina mögulega bótin er ísetning nýrrar loku, en vandasamt er að velja réttan tíma fyrir aðgerð hjá pessum sjúklingum Enginn er bættari með óparfa aðgerð, en á hinn bóginn eru lífslíkur verulega skertar um leið og einkenni koma fram. Pví miður koma margir sjúklingar ekki til athugunar fyrr en pá og benda erlendar rannsóknir til að allt að $30 \%$ sjúklinga sé neitað um aðgerð sökum aldurs, annarra ípyngjandi sjúkdóma eða lélegs ástands vinstri slegils. Pessar frábendingar eru pó afstæðar en ekki algildar og venjan er að læknar fleiri sérgreina komi að ákvörðunum um meðferð flókinna sjúkdómstilfella.

par til fyrir nokkrum árum var ekki gerlegt að skipta um ósæðarloku á annan hátt en með opinni hjartaaðgerð, en par sem pörfin fyrir aðra og minna ífarandi meðferð er mikil, hafa próast aðferðir til að koma fyrir nýrri loku. Kallast meðferðin Transcatheter aortic valve implantation (TAVI) á ensku, en eins og nafnið ber með sér er pessari lífrænu loku komið fyrir með hjálp præðingaleggs, oftast í gegnum náraslagæð, en sjaldnar í gegnum viðbeinsslagæð eða frá hjartabroddi, en pá parf jafnframt brjóstholsskurð. Вyrjað er á að spenna sundur kölkuðu lokuna og er nýja lokan síðan færð í samfallinni stöðu í lokustað og spennt par út í gömlu lokuna. Í slembirannsókn á 358 sjúklingum sem ekki voru taldir hæfir í skurðaðgerð vegna mikillar áhættu var eins árs dánartíðni 30,7\% í TAVI-hópnum en 50,7\% ( $p<0,001)$ í samanburðarhópnum sem hlaut lyfjameðferð. Ávinningur meðferðarinnar hjá pessum sjúklingahópi er af mörgum talinn ótvíræður prátt fyrir að snemmkomnir fylgikvillar séu enn algengir, en próun nýrra loka og tækni heldur áfram. Nýlega voru birtar niðurstöður úr slembaðri rannsókn sem miðaði að pví að kanna hvort árangur með TAVI væri lakari en með hefðbundinni lokuaðgerð hjá skurðtækum en há-áhættu sjúklingum og reyndist árangurinn sambærilegur, með eins árs dánartíðni 24,2\% og 26,8\% í hópunum tveimur. ${ }^{5}$ Í ljósi pessara niðurstaðna kunna ábendingar fyrir pessari meðferð að breytast og ná til stærra hóps sjúklinga pegar fram í sækir.

Vafalítið verða ósæðarlokuskipti með hefðbundinni skurðaðgerð áfram kjörmeðferð flestra sjúklinga sem purfa á lokuskiptum að halda, enda margsýnt fram á gagnsemi peirrar meðferðar. Hér á landi er pó að finna hjartasjúklinga sem ekki eiga kost á lokuskiptaaðgerð en gætu notið góðs af TAVI ef sú meðferð væri í boði líkt og í flestum nágrannalöndum okkar. Eins og gefur að skilja fylgir pví fjárfesting í kunnáttu og útbúnaði að taka upp TAVI og ljóst að kostnaðurinn verður ekki borinn af núverandi fjárframlögum einnar stofnunar. Раð er pví brýnt að stjórnendur heilbrigðismála taki afstöðu til pess hvernig best verði staðið að pví að nýta pessa nýju tækni sjúklingum okkar til hagsbóta.

\section{Heimildir}

1. Ingvarsdóttir IL, Viktorsson SA, Hreinsson $\mathrm{K}$, et al. Lokuskipti vegna ósæðarlokuprengsla á Íslandi 2002-2006: Ábendingar og snemmkomnir fylgikvillar. Læknablaðið 2011; 97: 523-7.

2. Nkomo VT, Gardin JM, Skelton TN, Gottdiener JS, Scott CG, Enriquez-Sarano M. Burden of valvular heart diseases: a population-based study. Lancet 2006; 368: 1005-11.

3. Hallgrímsson J. Chronic non rheumatic valvular heart disease. An autopsy study. Acta Pathol Microbiol Scand A 1976; 84: 247-52.

4. Leon MB, Smith CR, Mack M, et al. Transcatheter aorticvalve implantation for aortic stenosis in patients who cannot undergo surgery. N Engl J Med 2010; 363: 1597-607.

5. Smith CR, Leon MB, Mack MJ, et al. Transcatheter versus surgical aortic-valve replacement in high-risk patients. N Engl J Med 2011; 364: 2187-98.

Aortic valve replacement therapy - a new approach to come?

Thordis Hrafnkelsdottir MD, PhD, FESC Division of Research, Education and Innovation Landspitali 